\title{
VIOLENCE AS SOCIAL PATHOLOGY THROUGH THE OPTICS OF SOCIAL WORK
}

\author{
Hermína Mareková ${ }^{1}$
}

\begin{abstract}
Human aggression is perhaps the most interesting area in the exploration of the evolutionary behavior of mankind. Its existence is evident in our everyday lives, as we often use various kinds of violence, ranging from finer (innocent) coercions to murders and terrorist acts. In the professional world, as well as among laypersons, there are conflicting views on the assessment of aggression. Our work is an attempt to summarize the basics of the theory of violence. It is necessary to realize how divergent and inconsistent the various theories are. Attempts to define violence are subject to social norms. Even in scientific literature, some theories are highly dependent on the personal beliefs, points of view, and interests of the respective authors. An example is the opinion that humanity is currently experiencing its most peaceful time.

The questions of the necessity and impact of violence on our life constantly resonate in society and cannot be analyzed from only one angle. The aim of this paper is not to give a comprehensive picture of the problem of today's violence (including that found in the media), nor is our goal to find a single correct opinion on the topic, due to the extent of the problem. We rather attempt to contribute to the broadening of knowledge in this area and to propose more topics worth researching. We are inclined to utilize Husserl's methods of contemporary philosophy, with an emphasis on scientific precision and with the aim of creating a basis for further research.

Violence as a social pathology, with its social consequences, is largely addressed through social work. It is the cases where violence is often present, when the client as well as the social worker or the staff of other branches (police, health care) have to make decisions while having limited choices and, at the same time, trying to comply with the law.
\end{abstract}

UDC Classification: 304; DOI: http://dx.doi.org/10.12955/cbup.v6.1228

Keywords: aggression, violence, society, violence in the media

\section{Introduction}

Perhaps the most intriguing issue in evolutionary and socio-scientific research is the investigation of the existence of violence and its impact on society and, in particular, on the next human generation. Since the last century, various branches of science have studied the causes of violence with more effort. Disputes, about whether aggression is needed or not, whether it is instinctive, or whether it is learned during our socialization, have existed for centuries (Geen, 1988). In his classic works, Leviathan and De Cive, Tomas Hobbes claims that we, humans, in our natural form are wild animals and our aggression in society can be reduced only by our norms (order) (Hobbes, 1983, Hobbes, 2010). Hobbes (2010) calls it a natural aggressive instinct. In contrast, Jean Jacques Rousseau (1997), whose theory of the noble savage was first published in 1762, says that a person is naturally a very peaceful creature and that aggression comes to surface due to social barriers. This theory was elaborated by Freud (1948) in the twentieth century. According to him, man is born with a life-giving instinct (Eros) and a death instinct (Thanatos); these force us to be aggressive. According to social psychology, aggression is an activity that is deliberate. Many different professionals have long been looking for answers to the question, if violence is necessary, and what makes people commit violence. They have been trying to determine the degree of responsibility of the individual, as well as society. When examining violence in social sciences, the greatest problem is the existence of a number of different small theories, which often contradict each other. The theory of evolutionary psychology talks about family selection, the absence of the father in the family, preference for similarity, or fluctuating asymmetry (Bereczkei 2003, Buss 1995). Equally interesting is Campbell's theory of 1999, which explains gender differences in the use of violence (Campbell 1999).

But the fact remains that we often use violence, and in a society of aggressive children, youth and adults, the interactive consequence is that aggression causes further aggression.

Contradictory views also exist in the assessment of aggression in society. It has long been maintained that socialization is key in learning aggressive models of behavior. In the past, children used to socialize primarily in their families and schools. Nowadays a third socializing element - television and other media - enter the process. According to some sociologists, children are actually learning aggressive behaviour through the media. Other authors point out that it is much more the unresolved social problems or social differences, rather than television (the media environment) that are responsible for aggression in society. (Graham \& Gurr 1969, Coyne 2007).

\footnotetext{
${ }^{1}$ Danubius University, Sládkovičovo, Slovakia, hermina.marekova @ gmail.com
} 
Numerous researches represent an alternative approach, attempting at a cumulative view based on data obtained from different contexts. In social science research, it is important to look at social reality not only through quantitative research figures, because social reality is constructed in various ways. Predicted negative violence occurs in the life of society in the minds of people, both at the micro and the macro levels, and there is a change in norms, morality, and quite often a devaluation of the existing values takes place. In criminology, there are disputes about the frequency of crime in the past century as compared to this day and whether we now live in a more aggressive world. The English writer Wiliam Golding thought that the 20th century was the most violent century in the history of mankind. Unfortunately, nothing has changed for the better since that time (Golding, in Ondrejkovič, 2009). The manifestations and forms of violence are numerous, as are the causes of its origin.

\section{Aggression and violence in society}

The basic norm of our society is nonviolence and humanity, but from time to time, every person violates the rules of co-existence (the norms). Aggression and violence are undesirable phenomena for our society that we have classified as social pathology. If someone violates a norm that is recognized by the majority of society, such behavior is considered by the majority as a deviation. Deviant behavior is a violation of valid norms. The assessment of breaches of these norms varies in different eras and societies. Members of society cannot be strictly categorized into a group of persons who adhere to all norms, and a group who violate these norms. We respect social norms mainly because we have become accustomed to them and think that they are appropriate. We act so without further consideration or because failure to comply with these norms results in a sanction.

The Latin word aggredi, which forms the basis of the word aggression, means an attack or assault. Violence of humans affects mainly their social behaviour. It is a sign of offensive behaviour which usually occurs as a reaction to a real or apparent threat to one's power. However, the offensive behaviour itself may not only be a reaction to a threat to one's power. It can also be an intention to harm an individual or a group, and can manifest in an obvious way (beating, biting, etc.) or a hidden one (e.g. defamation, humiliation, etc.). Aggression most often brings about a damage to the norm. It is frequently an instrumental character, where it is an accompanying phenomenon of achieving goals, or an emotional character (emotional or hostile aggression). The readiness or predisposition to act aggressively is also understood as a part of aggression. Another form of aggression is tyrannization (bullying), which is usually a means of demonstrating control over someone or domination over others. Four groups of theories of aggression are usually distinguished in the sources: instinctive theories, frustration theories, social learning theories, and theories of aggression as a multi-causal phenomenon (Ondrejkovič, 1998, p. 350).

When attempting to summarize the basics of the theories of violence, it is necessary to realize how divergent and inconsistent the individual theories are. Attempts to define violence are subject to social norms. Even theories in scientific literature are highly dependent on beliefs, points of view, and the interests of the particular author.

In his theory, Fromm divides violence into two distinct groups. The first kind of violence, which we find in animals, is a biologically inevitable aggression. It is a response to attacks including defence (Fromm, 2001). When the threating situation is over, aggression also comes to an end. At the opposite end, there is malignant aggression, an assault that is typical of the human race, which is a propensity to destruction. In animals, we can actually observe a preference for defensive aggression, within which they do not torture, murder or hurt their kind. Biological, adaptive aggression's objective is to preserve life. Negative aggression is a human property that we cannot explain through only innate instincts. Its purpose is not the preservation and physical survival of the human race. It is a passion that in some cultures and in some individuals to be dominant, while in others is not. According to Csepeli (2002), aggression is such a relationship between people or groups, in which one's activity turns against another and causes psychological, physical or material harm. It is a destructive behavior whose aim is to destroy. The goal of aggression is non-existence, and its assumption is the existence of something that can be destroyed.

Crime and deliberate aggression, occurs when the criminal is aiming exclusively to harm. Ranschburg calls this aggression "aggression in anger", where the only motivation for the perpetrator is to cause 
the other pain and inconvenience. Myers calls this type "hostile aggression inspired by others" (Myers 1987).

Deliberate aggression in interpersonal relationships raises tensions, interfering with cohabitation in partner relationships. Examples of such aggression are provocation, quarrels, defamation, malevolence, sarcasm, which often bring joy to the performers, but ruin the social atmosphere around them. The group manifestations of such aggression are vandalism, lynching, pogroms (from Russian massive violence against a group of people) (Buchtelová et al., 1977, 721) where a group without choice destroys everything that it comes in contact with: people, buildings, park benches, railway carriages, etc. They try to destroy everything that has a value.

It appears that the good in the world must first be prominent in order to be destroyed by aggression. The more perfectly the goal of aggression is fulfilled, the more the aggression destroys its own existence. Destruction eventually ends with destruction. The definition of aggression implies that the occurrence of visible psychological or physical harm can only be called aggression, if it is preceded by a wish to harm.

It is an illusion to think that aggression can disappear from our lives and only good will remain. The truth is that aggressive behavior often occurs for the sake of good. In the case of instrumental aggression, antisocial action within the realization of the ideology of goodness appears to be prosocial. A typical example of such behavior was the raping of women in Bosnia during the war. Killing men in the war represents the physical destruction of the enemy. In the war in Bosnia, according to ideology, the enemy must have been eliminated. The goal was achieved by the physical destruction of men and the symbolic destruction of women by way of rape (Salec, 1994).

Self-assertion "at any price" in certain circumstances obviously encourages individuals to act aggressively while adhering to the terms and conditions of a competition. Inventiveness, violence and aggressive behavior are viewed as ethical through the prism of performance orientation. (McClelland Austin, 1961). Rules are created by winners, starting conditions are uneven, and the biological selection theory cannot be used in society.

The parent-child relationship is a typical double bond, where the parent under the pretext of parental love directs his/her aggression towards the child. Actually, parents hide their bans, orders, and punishments under the guise of parental love. The parents restrict the child to an almost unbearable extent and, at the same time, very severely punish every move of the child towards liberation and emphasize how they love the child, how they cook, wash, work for the child and sacrifice their most beautiful years. The child does not understand this contradiction and feels an increasing guilt for their ingratitude. Anxiety and decline in self-confidence are not counterbalanced by parental love (Ranschburg, 2003). In this case, the one who loves, wants to own, wants to decide, control, and limit the object of their love. It's an unsymmetrical relationship, but it promises security. However, not every partner wants or is able to meet Pygmalionic urges.

Violence, according to Ondrejkovič (1998, p. 362), "is the most common designation of a single case of such physical act, in which one person causes harm to another person. It is also used as a term naming forms of intervention into relationships, which is regulated by law, or as a term for the farreaching direct or indirect influence upon people. Violence can also be incorporated into the very structure of the social system."

Every day we hear about cases where police authorities use coercive means. The second example in this category is the army. The ideological context determines whether a murderer is a hero for the sake of good, or a malevolent killer. It is interesting to find out what different reasons were used to defend the start of a war, or to initiate any violence, such as in the name of God, fate, natural law, responsibility, peace, liberty, security, independence, truth, treaty, majority will, birthright, blood bond, culture, status quo, public opinion, vendetta, liberation, etc. Violence is most often justified by defense (defense of society). In modern society, there is a great desire for a just world, where interpersonal relationships are governed by the desire for justice. According to this, shortcomings should not outweigh benefits in the long run. This view also serves to legitimize prison sentences on the basis of court decisions. 


\section{Media violence}

We learn during socialization all the competences necessary for us to be able to integrate, to find our way in society, to coexist. This learning most often takes places in a well-functioning family. At the present time all age groups are attacked, on a daily basis, by patterns, models broadcast not only by schools, but also by mass communication, youth subculture as well as the media. We guess or perhaps know for sure that the media influences us. Opinions about the impact of the media on our lives vary and research is being done on this topic. It is not rare that these studies completely oppose each other. Reliability of this research would greatly benefit from a precise stipulating of what is considered violence and what is aggression. It is important in order to make a meaningful assessment of the impact of the media on people. We know that the view of nice faces induces positive responses in the brain (Aharonet et al., 2001). What do we know about what a view of violence, that is present in every culture, induces? (Ellera 2006). The display of violence in the media has direct consequences (lasting a few seconds), and with various examination methods, these changes can be captured neurophysiologically, hormonally, etc. During the evolution of humans, the most threatening factor for an individual in his environment has always been another human individual (Duntley 2005). The media reflect the fact that stories of violence and murders are abundant in literature. The immersion into these stories generates strong feelings and apparently serves for entertainment. But they also represent certain norms and values, including those that contradict the norms and values currently valid in our culture.

\section{Violence in the family and the possibilities of social assistance to the victims of domestic violence}

The smallest unit of society is still the family, where family members are united by marriage, blood relation, or adoption. Economically, it represents a shared household under one roof, and it may also mean a joint production activity. Today, some family functions are subdued, but raising offspring still remains an important family function (socialization). The family is an institution protected and regulated by society, which means that its members have both rights and obligations. A wellfunctioning family provides emotional stability, relaxation for their members, and is the ideal environment to care for the sick and the old. For women, it brings about a certain tension when they strive to reconcile their social self-realization, their career, with the role of the mother in the family. At the same time, it is also stressful for men, because this emancipation destabilizes the traditional roles definition in the family. Role conflicts in the family are very frequent. More traditional domestic work is done by women, as well as care for the elderly and the sick, and frequently also for the man's family members. Social work comes into play in the case of domestic violence, which is most often committed against women, children and the elderly. However, many cases remain hidden, because women do not like to talk about humiliation in the home. The ways to help victims of domestic violence include improving their awareness (leaflets, websites) as well as qualified assistance from supporting professions and institutions that can be contacted with a request for help. It is this area assistance to the family through reform, but also by way of legislation - which is still lagging behind. Šebestová (2012) states that many of us automatically ask the question of why, for example, in the social field, unfavorable reforms are adopted. They sometimes include changes affecting the most vulnerable groups of the population to such an extent that the rights to preserve human dignity and equality of every citizen before the law are questioned. Legislation, after all, does not divide people into the rich and the poor, into seniors or people with disabilities, but guarantees the irremovability, impenetrability, immeasurability and irrevocability of basic human rights and freedoms to every citizen. This means that a state declaring certain values is also expected to be the guarantor of social justice and values. One of the causes of this condition may be the surviving stereotypical thinking as well as a mass appearance of individualities, the crisis of the family, changes in cohabitation as well as changes in values. "Our ideals are constantly changing", wrote Fritz Bohnsack in 1996 and said that significant changes in the recognition of previously existing values have occurred. According to him, a few decades ago the accepted, recognized, valid values and norms in society used to be qualities such as submission, discipline, performance of duties, reliability, openness, loyalty, punctuality, selfsacrifice for the good of society, and modesty. German sociology calls them the values of duty and acceptance. The new values are called the values of self-actualization. Such values include spontaneity, pleasure seeking, self-fulfillment, and immediate satisfaction of someone's needs. "Not everyone accepts it, but most of society lives according to it", says Bohnsack (1996). Despite these 
changes, a well-functioning family is still considered the ideal environment for regeneration, emotional balance, and care of the sick and the elderly. Social assistance is supposed to work for the benefit of the family in cases of social pathology. However, there are no relevant studies available, which would explore what the family really needs to deal successfully with a crisis situation.

\section{Conclusion}

The environment that determines our behaviour consists of a mosaic of various attributes. Perhaps the most important factor of those is the aspect of morality, worldview, religion, law, and existing politics. However, we are unfinished people, "fortunately," says Hankiss. Or, as Nicolai Hartmann puts it, "only an unfinished person can be free," so there are a million possibilities of how life can deal with problems. This is why some important as well as less important thoughts have found their way into this work. The topic of violence is very extensive, and this article cannot tackle the whole issue. It attempts to shed some light on the main aspects of violence in our society. We live in a very hectic age, and here in Europe, the most violent issue is the proliferation of violence that was unknown to the previous generations. Changes are remarkable both in the family and in society. Detailed analysis and observation, recognition of phenomena in society can be a good means of eliminating social differences and can help in the rehabilitation of integration disorders.

\section{Acknowledgement}

This scientific article was created within the operational program Research and Development for the project "Modernization and Building Technical Infrastructure to Support and Develop the Scientific and Research Potential" of Danubius University, Sládkovičovo. ITMS 26210120047. The project is jointly financed from the European Regional Development Fund and the Research Agency of the Slovak Ministry of Education.

\section{References}

Aharon, I., et al. 2001. Beautiful faces have variable reward value: fMRI and behavioral evidence. Neuron, 32,537 - 551.

Bereczkei, T., 2003. Evolúciós psychológia. Osiris. Budapest. 2003. 542 pp. ISBN: 963389476X

Bohnsack, F., \& Leber, S. (1996). Sozial-Erziehung im Sozial-Verfall (p. 384). Weinheim: Beltz.

Buchtelová, R., Confortiová, H., Červená, V., Holubová, V., Hovorková, M., Churavý, M., Kraus, J., Kroupová, L., Ludvíková, M., Machač, J., Mejstř́ik, V., Petráčková, V., Poštolková, B., Roudný, M., Schmiedtová, V., Šroufková, M., \& Ungermann, V. (2008). Slovnik cudzich slov (3rd ed., p. 1054). Bratislava: SPN - Mladé letá, Ltd.

Buss,D.M. 1995. Evolutionary Psychology: A New Paradigm for Psychological Science. Psychological Inquiry, 6:1 - 30 (Evolúciós psychológia: Új paradigma Bereczkei T., szerk. 2001. Lélek ésevolúció. Az evolúciós szemléletés a pszichológia. Budapest. Osiris., 367 - 425.

Campbell, A. 1999. Stayong Alive: Evolution Culture and Women's Inrian Sciences. 22. 203 - 214.

Coyne, S. 2007. Does Media Violence Crime European Journal on Criminal Policy and Researcg, 13: 205 - 211.

Csepeli, G. 2002. Szociálpszichólogia. Budapest: Osiris, 2002, 570 pp. ISBN 963-379-563-X.

Duntley, J. D. 2005. Adaptation to dangers from humans. In: Buss, David M. John Wiley \& (eds). : The handbook of evolutionary psychology. Hoboken, NJ, John Wiley \& Sons. 234 - 249.

Ellera, J. D. 2006. Violence and Culture. Belmont, CA. Thomson \& Wadswort

Freud, S. 1948. Beyond the pleasure principe. Hogart Press and Institute of Psycho-Analysis. London.

Fromm, E. 2001. A rombolásanatómiája. Budapest: Háttérkiadó, 2001, 721 pp. ISBN 963-8128-94-1.

Geen, R. 1988. Aggression. McGraw-Hill. New York

Graham, H. D., Gurr, T. R. 1969. Violence in America: Historial and Comparatíve Perspectíve: A Report to the National Comission on the Causes and Prevetion of Violence. Washington, DC.: Goverment Printing Office.

Golding, W. G. 2009. Ondrejkovič, P., Bakošová, Z., Bednárik, R., Kasanová, A., Lubelcová, G., Marková, D., Masár, O., Miková, Z., Nábelěk, L., Poláková, E., Poliaková, E., Rusnáková, J., Sedláková, D., Šramová, B., 2009. Sociálna patológia. str. 125. Veda. Vydavatel'stvo SAV. 2009. Bratislava: ISBN 978-80-224-1074-8. 578 pp.

Hankiss, E., 2015. A befejezetlenember. Budapest. Helikonkiadó. 342 pp. ISBN 9-789632-274966

Hartmann, N. 2015. In Hankiss, E., 2015. A befejezetlenember. Budapest. Helikonkiadó. 342 pp. ISBN 9-789632-274966

Hobbes, T. 1983. De Cive. Oxford University Press. New York. 290 pp. ISBN 0-19-824623-4

Hobbes, T. 2010. Leviathane. Vydavatel'stvo OIKOYMENH. 513 s. ISBN 9788072981069

McClelland, D. L., - Austin, J. B. The Achieving Society. New York, Van Nostrand reinhold, 1961. In Csepeli, G. 2002. Szociálpszichólogia. Budapest: Osiris, 2002, 570 pp. ISBN 963-379-563-X.

Myers, D. G. 1998. Socialpsychology. 2nd ed. New York. McGraw - Hill, 1987. In Csepeli, G. 2002. Szociálpszichólogia. Budapest: Osiris, 2002, 570 pp. ISBN 963-379-563-X. 
Ondrejkovič, P. 1998. Úvod do sociológie výchovy. Teoretické základy sociológie výchovy a mládeže (p. 381). SAV. Bratislava. Veda

Ranschburg, J. 2003. Félelem, harag, agresszió. Budapest: NTK, 2003, 161 pp. ISBN 963-19-1303-1.

Rousseau, J. J. 1997. The social contract and discourses. Dutton, New York - A társadalmiszerzodésrol, avagy a politika ijogelvei. Pannon Klett Kiadó. Budapest. 1997.

Salec, R. 1994. The ideology of the Mother Nation in the Yugoslav konflikt. In Kennedy, M. (ed.) Envisioning Eastern Europa, An Arbor, University of Michigen Press. Csepeli, G. 2002. Szociálpszichólogia. Budapest: Osiris, 2002, 570 pp. ISBN 963-379-563-X.

Šebestová, P. 2012. Ambivalentnost' reformnej paradigmy sociálnej práce. In Starnutie populácie - celospoločenský problém: zborník z vedeckej konferencie s medzinárodnou účastou - Katedra sociálnych služieb a poradenstva FSV Univerzity Cyrila a Metoda v Trnave, 2012. ISBN 978-80-8105-397-9 